\title{
PENEGAKKAN HUKUM TERHADAP PELAKU TINDAK PIDANA PRANK \\ BERDASARKAN KITAB UNDANG-UNDANG HUKUM PIDANA DAN \\ UNDANG-UNDANG INFORMASI DAN TRANSAKSI ELEKTRONIK \\ (PENGHINAAN YANG DIUNGGAH DI MEDIA ONLINE)
}

\section{Oleh :}

\author{
Dwi Wachidiyah Ningsih*, Abdul Karim** \\ * Fakultas Hukum, Universitas Gresik \\ Email : dwiwachidiyah24@gmail.com \\ ** Fakultas Hukum, Universitas Gresik \\ Email : abdkarim1430@gmail.com
}

\begin{abstract}
ABSTRAK
Sering kali pelaku prank luput dari jerat hukum. Tidak semua korban prank bersedia melaporkan ke kepolisian. Penelitian ini bertujuan untuk mengetahui penegakkan hukum tindak pidana prank (penghinaan yang diunggah di media online) sesuai dengan Kitab Undang-Undang Hukum Pidana dan Undang-Undang Nomor 11 Tahun 2008 tentang Informasi dan Transaksi Elektronik dan untuk mengetahui langkah hukum untuk menjerat tindak pidana prank (penghinaan yang diunggah di media online) yang sesuai dengan dengan Kitab Undang-Undang Hukum Pidana dan Undang-Undang Nomor 11 Tahun 2008 tentang Informasi dan Transaksi Elektronik. Penelitian ini merupakan peneltian yuridis normatif. Pendekatan yang digunakan dalam penelitian ini adalah pendekatan perundang-undangan. Sumber bahan hukum berasal dari bahan hukum primer. Teknik pengumpulan bahan hukum dengan studi dokumen menggunakan metode content analysis. Teknik analisa bahan hukum dilakukan dengan kualitatif. Penegakkan hukum tindak pidana prank (penghinaan yang diunggah di media online) adalah sesuai dengan Kitab Undang-Undang Hukum Pidana Pasal 310 KUHP dan sesuai dengan Pasal 45 ayat (1) Undang-Undang Nomor 11 Tahun 2008 tentang Informasi dan Transaksi Elektronik. Langkah hukum untuk menjerat tindak pidana yang sesuai dengan dengan Kitab Undang-Undang Hukum Pidana dan Undang-Undang Nomor 11 Tahun 2008 tentang Informasi dan Transaksi Elektronik.
\end{abstract}

Kata Kunci : Tindak Pidana, Prank, Pencemaran Nama Baik, Media Online ABSTRACT

Often prankers escape the trap of the law. Not all prank victims are willing to report to the police. This study aims to determine the law enforcement of prank criminal acts (insults uploaded in online media) in accordance with the Criminal Code and Law Number 11 of 2008 concerning Electronic Information and Transactions and to find out legal steps to ensnare prank crime (insults uploaded in online media) in accordance with the Criminal Code and Law Number 11 of 2008 concerning Electronic Information and Transactions. This research is a normative juridical research. The approach used in this research is a statutory approach. The source of legal materials comes from primary legal materials. The technique of collecting legal materials by studying documents uses the content analysis method. Legal 
material analysis techniques are carried out qualitatively. Prank criminal law enforcement (insults uploaded on online media) are in accordance with the Criminal Code Article 310 of the Criminal Code and in accordance with Article 45 paragraph (1) of Law Number 11 of 2008 concerning Electronic Information and Transactions. Legal steps to prosecute criminal acts in accordance with the Criminal Code and Law Number 11 of 2008 concerning Electronic Information and Transactions.

\section{Keywords: Crime, Prank, Defamation, Online Media}

\section{Pendahuluan}

\subsection{Latar Belakang}

Teknologi informasi dan komunikasi dalam praktiknya tidak hanya digunakan sebagai sarana untuk berkomunikasi, namun juga sebagai hiburan. Adanya kebutuhan tersebut, teknologi informasi menciptakan berbagai aplikasi dan portal-portal hiburan online seperti Youtube untuk streaming video-video menghibur hingga membuat penonton tertawa. Akan tetapi, kemudahan yang diberikan teknologi informasi membuat sebagian orang menyalahgunakannya.

$$
\text { Penyalahgunaan teknologi }
$$

informasi dapat berupa membuat konten berita palsu, pelanggaran hak cipta seperti mengunggah video dengan tema atau konten tertentu yang telah memiliki hak cipta, pencemaran nama baik dalam bentuk video, foto, tulisan yang dipublikasikan, dan lainlain. Pencemaran nama baik yang sedang popular di kalangan masyarakat saat ini adalah pencemaran nama baik dengan mengunggah video prank.

Prank merupakan sesuatu yang
tidak asing lagi dikalangan masyarakat, terutama anak muda yang memiliki tingkat selera humor yang tinggi. Prank adalah suatu bentuk slang atau sebutan yang tidak resmi untuk kejenakaan, yang diadaptasi dari practical joke, dan bertujuan untuk membuat orang dalam hal ini korban merasa terjahili sehingga menimbulkan rasa kepuasan pada pembuat prank. Prank memiliki berbagai jenis, diantaranya adalah prank dengan menggunakan berbagai tema, salah satunya adalah tema kejahilan dengan memberi kejutan kepada orang lain dengan cara membohongi seperti yang dilakukan oleh YouTuber Ferdian Paleka.

Ferdian Paleka dan temantemannya memberikan bantuan dalam kemasan kardus yang ternyata berisi sampah. Korban yang dipilih adalah transpuan yang ditemuainya dijalanan. Ferdian dan teman-temannya ini mengaku membuat konten prank tersebut demi meningkatkan jumlah pengikut atau subscriber di kanal Youtube miliknya. Konten seperti itu bagi pembuatnya akan membantu upaya untuk menambah subscriber di kanal Youtube, namun bagi korban jelas merugikan. Korban yang video pranknya dimuat di Youtube akan merasa terhina dan malu. Bagi korban, Ferdian dan teman-temannya telah mencemari nama baik korban dengan mengunggah video prank tersebut.

Jika dilihat dari Pasal 40 ayat (1) huruf M Undang-undang No 28 Tahun 2014 tentang Hak Cipta, Ciptaan yang Dilindungi, video prank terhadap diri korban yang diambil oleh YouTuber tersebut dikategorikan sebagai ciptaan yang dilindungi, yaitu karya sinematografi. "Karya sinematografi" yang dimaksud adalah ciptaan yang berupa gambar bergerak (moving images) antara lain film 
dokumenter, film iklan, reportase atau film cerita yang dibuat dengan skenario, dan film kartun. Karya sinematografi dapat dibuat dalam pita seluloid, pita video, piringan video, cakram optik dan/atau media lain yang memungkinkan untuk dipertunjukkan di bioskop, layar lebar, televisi, atau media lainnya. Sinematografi merupakan salah satu contoh bentuk audiovisual.

Meski membuat konten prank bukan termasuk pelanggaran hak cipta namun konten prank dalam bentuk video yang disebar di internet yang melukai dan merendahkan kehormatan sesorang dapat dijerat pidana. Video yang diambil melalui kamera oleh YouTuber tersebut dapat dikatakan sebagai informasi elektronik dan/atau dokumen elektronik sebagaimana yang terdapat dalam Pasal 1 angka 1 dan angka 4 UU 19/2016 tentang Perubahan atas Undang-Undang Nomor 11 Tahun 2008 tentang Informasi dan Transaksi Elektronik.

YouTuber yang mengunduh video prank yang membuat malu korban sebagai orang yang dijahili dalam video tersebut dapat dikenai sanksi pidana. Tindakan YouTuber tersebut dapat dikategorikan sebagai tindakan penghinaan atau pencemaran nama baik yang diatur dalam Pasal 310 Kitab Undang-undnag Hukum Pidana (KUHP).

Penjelasan Pasal 310 KUHP menerangkan bahwa menghina adalah menyerang kehormatan dan nama baik seseorang. Pihak yang diserang ini biasanya merasa malu, Kehormatan yang diserang di sini hanya mengenai kehormatan tentang nama baik, bukan kehormatan dalam lapangan seksuil, kehormatan yang dapat dicemarkan karena tersinggung anggota kemaluannya dalam lingkungan nafsu birahi kelamin. ${ }^{1}$

Supaya dapat dihukum menurut pasal ini, maka penghinaan itu harus dilakukan dengan cara menuduh seseorang telah melakukan perbuatan tertentu dengan maksud agar tuduhan itu tersiar (diketahui oleh orang banyak). Perbuatan yang dituduhkan itu tidak perlu suatu perbuatan yang boleh dihukum seperti mencuri, menggelapkan, berzina dan sebagainya, cukup dengan perbuatan biasa, sudah tentu suatu perbuatan yang memalukan.

Sedangkan pasal yang mengatur mengenai penghinaan dan pencemaran nama baik melalui media elektronik (video) diatur dalam Pasal 27 ayat (3) UU ITE sebagai berikut: "Setiap Orang dengan sengaja dan tanpa hak mendistribusikan dan/atau mentransmisikan dan/atau membuat dapat diaksesnya Informasi Elektronik dan/atau Dokumen Elektronik yang memiliki muatan penghinaan dan/atau pencemaran nama baik.

Jadi perbuatan YouTuber mengunggah video prank yang membuat korban menjadi malu dapat dijerat dengan pidana atas pencemaran nama baik berdasarkan Pasal 27 ayat (3) UU ITE jo. Pasal 45 ayat (3) UU 19/2016 tentang Perubahan atas Undang-Undang Nomor 11 Tahun 2008 tentang Informasi dan Transaksi Elektronik. Namun perlu diingat bahwa agar dapat dijerat pidana, korban harus melakukan pengaduan karena ketentuan penghinaan atau pencemaran nama baik dalam UU 19/2016 tentang Perubahan atas Undang-Undang Nomor 11 Tahun

\footnotetext{
${ }^{1}$ R. Soesilo, Kitab Undang-Undang Hukum Pidana (KUHP) Serta KomentarKomentarnya Lengkap Pasal Demi Pasal, Peliteia, Bogor, 1995, h. 225.
} 
2008 tentang Informasi dan Transaksi Elektronik merupakan delik aduan.

Mengingat ketentuan penghinaan atau pencemaran nama baik merupakan delik aduan, sering kali pelaku prank luput dari jerat hukum. Tidak semua korban prank bersedia melaporkan ke kepolisian. Korban merasa malu dan tidak mau memperpanjang urusan meski dirinya dirugikan. Selain itu, tidak semua korban mengetahui langkah hukum apa yang bisa ditempuh jika akan melaporkan pelaku prank ke kepolisian. Oleh karena itu, perlu adanya penagakan hukum yang tegas dan tidak tergantung dengan pengaduan yang disampaikan oleh korban, mengingat nama baik korban yang terancam tercemar dan mempengaruhi kondisi sosialnya.

Berdasarkan latar belakang diatas maka penulis tertarik untuk meneliti penegakkan hukum pelaku prank berdasarkan KUHP dan perundang-undangan yang mengatur tindak pidana prank tersebut.

\subsection{Rumusan Masalah}

1. Bagaimana penegakan hukum tindak pidana prank (penghinaan yang diunggah di media online) sesuai dengan Kitab UndangUndang Hukum Pidana dan Undang-Undang Nomor 11 Tahun 2008 tentang Informasi dan Transaksi Elektronik?

2. Bagaimana langkah hukum untuk menjerat tindak pidana prank (penghinaan yang diunggah di media online) yang sesuai dengan Kitab Undang-Undang Hukum Pidana dan Undang-Undang Nomor 11 Tahun 2008 tentang Informasi dan Transaksi Elektronik?

\section{Tinjauan Pustaka}

\subsection{Tindak Pidana}

Tindak pidana adalah perbuatan yang dilarang oleh suatu aturan hukum, yang mana larangan ini disertai dengan ancaman (sanksi) yang berupa pidana tertentu bagi barang siapa yang melanggar larangan tersebut.

Menurut Prof. Moeljatno unsur tindak pidana yaitu sebagai berikut, yakni: ${ }^{2}$

1. Perbuatan;

2. Yang dilarang (oleh aturan hukum); dan

3. Ancaman pidana (yang melanggar larangan).

Pada dasarnya, tindak pidana mempunyai 2 unsur yaitu unsur subjektif dan unsur objektif. ${ }^{3}$
2 Adami Chazawi, Pelajaran Hukum Pidana (Stelsel Tindak Pidana, Teori-Teori Pemidanaan \& Batas Berlakunya Hukum Pidana , Raja Grafindo Persada, Bandung. 2002, h. 79.

3 P.A.F. Lamintang, Dasar-dasar Hukum Pidana Indonesia, Citra Aditya Bakti, Jakart.1997 h. 193 
1. Unsur Subjektif :

Unsur subjektif adalah unsurunsur yang melekat pada diri si pelaku atau yang berhubungan dengan diri si pelaku, dan termasuk ke dalamnya yaitu segala sesuatu yang terkandung di dalam hatinya.

a. Kesengajaan atau ketidaksengajaan (dolus atau culpa)

b. Maksud atau Voornemen pada suatu percobaan atau pogging seperti yang dimaksud dalam Pasal 53 ayat 1 KUHP

c. Macam-macam maksud atau oogmerk seperti yang terdapat misalnya di dalam kejahatankejahatan pencurian, penipuan, pemerasan, pemalsuan dan lain-lain;

d. Merencanakan terlebih dahulu atau voorbedachte raad seperti yang terdapat di dalam kejahatan pembunuhan menurut Pasal 340 KUHP;

e. Perasaan takut yang antara lain terdapat di dalam rumusan tindak pidana menurut Pasal 308 KUHP

2. Unsur-unsur objektif suatu tindak Pidana Unsur objektif adalah unsur-unsur yang ada hubungannya dengan keadaankeadaan, yaitu di dalam keadaan di mana tindakan-tindakan dari si pelaku itu harus di lakukan:

1) Sifat melawan hukum atau wederrechttelijkheid.

2) Kualitas dari pelaku, misalnya keadaan sebagai seorangpegawai negeri.

3) Kausalitas, yakni hubungan antara suatu tindak pidana sebagai penyebab dengan sesuatu kenyataan sebagai akibat.Selain itu, unsur-unsur tindak pidana dapat dilihat menurutbeberapa teoretis.

Teoretis artinya berdasarkan pendapat para ahli hukumyang tercermin pada bunyi rumusannya.

\subsection{Prank}

Prank diambil dari kata berbahasa inggris yang mempunyai arti kelakar, olok-olok, seloroh, senda gurau, menipu atau mengibuli. ${ }^{4}$ Dapat diartikan dengan seseorang yang ingin berbuat jahil kepada temannya dan mereka akan mengagetkan temannya dan mengerjainya, kemudian mereka akan saling menertawakannya.

Prank adalah suatu bentuk slang atau sebutan yang tidak resmi untuk kejenakaan, yang diadaptasi dari practical joke, dan bertujuan untuk membuat orang dalam hal ini korban merasa terjahili sehingga menimbulkan rasa kepuasan pada pembuat prank. Prank memiliki berbagai jenis, diantaranya adalah prank dengan menggunakan tema kejahataan, seperti menculik, menodongkan senjata tajam, ataupun bertindak sebagai preman yang berpura-pura mengancam korban kejahilannya.

Prank juga bisa berarti lelucon atau guyonan yang sengaja dibuat oleh seseorang dari sesuatu yang awalnya mengandung konten negatif seperti pornografi, kekerasan, vandalism, tragedy, sarkasme serta hinaan terhadap golongan tertentu, yang bisa mengandung makna mengerikan atau kejam di balik leluconnya. Prank itu lucu namun bisa merembet ke ranah hukum. Walaupun sifatnya bercanda, prank yang sifatnya dark humor itu bisa merugikan orang lain. Sehingga

\footnotetext{
${ }^{4}$ John M. Echols dan Hassan Shadily, Kamus Inggris-Indonesia. PT. Gramedis Jakarta. 2008. h 442.
} 
bercandaan ini bisa sampai dibawa ke ranah hukum.

\subsection{Ketentuan Pidana Pelaku Prank}

Video yang berkonten prank yang diambil melalui kamera oleh YouTuber tersebut dapat dikatakan sebagai informasi elektronik dan/atau dokumen elektronik sebagaimana yang terdapat dalam Pasal 1 angka 1 dan angka 4 UU 19/2016 tentang Perubahan atas Undang-Undang Nomor 11 Tahun 2008 tentang Informasi dan Transaksi Elektronik:

"Informasi Elektronik adalah satu atau sekumpulan data elektronik, termasuk tetapi tidak terbatas pada tulisan, suara, gambar, peta, rancangan, foto, electronic data interchange (EDI), surat elektronik (electronic mail), telegram, teleks, telecopy atau sejenisnya, huruf, tanda, angka, Kode Akses, simbol, atau perforasi yang telah diolah yang memiliki arti atau dapat dipahami oleh orang yang mampu memahaminya"

Pasal 1 angka 4 UU 19/2016 tentang Perubahan atas UndangUndang Nomor 11 Tahun 2008 tentang Informasi dan Transaksi Elektronik

"Dokumen Elektronik adalah setiap Informasi Elektronik yang dibuat, diteruskan, dikirimkan, diterima, atau disimpan dalam bentuk analog, digital, elektromagnetik, optikal, atau sejenisnya, yang dapat dilihat, ditampilkan, dan/atau didengar melalui Komputer atau Sistem Elektronik, termasuk tetapi tidak terbatas pada tulisan, suara, gambar, peta, rancangan, foto atau sejenisnya, huruf, tanda, angka, Kode Akses, simbol atau perforasi yang memiliki makna atau arti atau dapat dipahami oleh orang yang mampu memahaminya.

Konten prank dalam bentuk video yang di upload ke internet yang dapat merendahkan kehormatan atau mencemarkan nama baik seseorang jika mengacu dapat dikategorikan sebagai tindakan penghinaan atau pencemaran nama baik yang diatur dalam Pasal 310 Kitab UndangUndang Hukum Pidana (“KUHP”).

Pasal 310 KUHP menerangkan bahwa Menghina" adalah "menyerang kehormatan dan nama baik seseorang". Yang diserang ini biasanya merasa "malu", "Kehormatan" yang diserang di sini hanya mengenai kehormatan tentang "nama baik", bukan "kehormatan" dalam lapangan seksuil, kehormatan yang dapat dicemarkan karena tersinggung anggota kemaluannya dalam lingkungan nafsu birahi kelamin. ${ }^{5}$

Supaya dapat dihukum menurut pasal ini, maka penghinaan itu harus dilakukan dengan cara "menuduh seseorang telah melakukan perbuatan tertentu" dengan maksud agar tuduhan itu tersiar (diketahui oleh orang banyak). Perbuatan yang dituduhkan itu tidak perlu suatu perbuatan yang boleh dihukum seperti mencuri, menggelapkan, berzina dan sebagainya, cukup dengan perbuatan biasa, sudah tentu suatu perbuatan yang memalukan. ${ }^{6}$

Sedangkan pasal yang mengatur mengenai penghinaan dan pencemaran nama baik melalui media

\footnotetext{
${ }^{5}$ R. Soesilo, Op. Cit, h. 225.

${ }^{6}$ Ibid
} 
elektronik (video) diatur dalam Pasal 27 ayat (3) UU ITE sebagai berikut: "Setiap Orang dengan sengaja dan tanpa hak mendistribusikan dan/atau mentransmisikan dan/atau membuat dapat diaksesnya Informasi Elektronik dan/atau Dokumen Elektronik yang memiliki muatan penghinaan dan/atau pencemaran nama baik.

Ancaman pidana bagi orang yang melanggar Pasal 27 ayat (3) UU ITE ini diatur dalam Pasal 45 ayat (3) UU 19/2016, yang berbunyi:

"Setiap Orang yang dengan sengaja dan tanpa hak mendistribusikan dan/atau mentransmisikan dan/atau membuat dapat diaksesnya Informasi Elektronik dan/atau Dokumen Elektronik yang memiliki muatan penghinaan dan/atau pencemaran nama baik sebagaimana dimaksud dalam Pasal 27 ayat (3) dipidana dengan pidana penjara paling lama 4 (empat) tahun dan/atau denda paling banyak Rp750.000.000,00 (tujuh ratus lima puluh juta rupiah)".

Dengan demikian perbuatan YouTuber mengunggah video prank yang membuat korban menjadi malu dapat dijerat dengan pidana atas pencemaran nama baik berdasarkan Pasal 27 ayat (3) UU ITE jo. Pasal 45 ayat (3) UU 19/2016.

\subsection{Pencemaran Nama Baik di Media Online}

Pencemaran nama baik dikenal juga dengan istilah penghinaan, yang pada dasarnya adalah menyerang nama baik dan kehormatan seseorang yang bukan dalam arti seksual sehingga orang itu merasa dirugikan. kehormatan dan nama baik memiliki pengertian yang berbeda, tetapi keduanya tidak dapat dipisahkan satu dengan yang lain, karena menyerang kehormatan akan berakibat kehormatan dan nama baik tercemar, demikian juga menyerang nama baik akan berakibat nama baik dan kehormatan seseorang dapat tercemar, oleh sebab itu, menyerang salah satu diantara kehormatan atau nama baik sudah cukup dijadikan alasan untuk menuduh seseorang telah melakukan penghinaan. $^{7}$ Oemar Seno Adji mendefinisikan pencemaran nama baik adalah menyerang kehormatan atau nama baik (aanranding of geodenaam). Salah satu bentuk pencemaran nama baik adalah "pencemaran nama baik secara tertulis dan dilakukan dengan menuduh sesuatu hal". 8

Unsur-unsur penghinaan ringan (eenfoudige beleediging) dirumuskan dalam pasal 315 tiap-tiap penghinaan dengan sengaja atau tidak bersifat pencemaran atau pencemaran tertulis yang dilakukan terhadap seseorang baik dimuka umum dengan lisan atau tulisan, maupun dimuka orang itu sendiri dengan lisan atau perbuatan, perbuatan, atau dengan surat yang dikirimkan atau diterima kepadanya, diancam karena penghinaan ringan dengan pidana penjara paling lama empat bulan dua minggu atau pidana denda paling banyak empat ribu lima ratus rupiah.

\section{Metode Penelitian}

\subsection{Jenis Penelitian}

Jenis penelitian yang digunakan adalah penelitian yuridis normatif, yakni bahan hukum primer yang terdiri dari kaidah, ketentuan atau peraturan dasar, serta peraturan

7 Mudzakir, ADR; Penyelesaian Perkara Pidana dalam Sistem Peradilan Pidana Indonesia, Makalah Workshop, Jakarta, h. 18.

${ }^{8}$ Oemar Seno Adji, Perkembangan Delik Pers di Indonesia, Erlangga, Jakarta, 1990, h. 36. 
perundang-undangan maupun literatur yang materi yang dibahas untuk memecahkan fakta atau persoalan hukum yang ada.

\subsection{Pendekatan Penelitian}

Pendakatan masalah dalam penelitian ini dianalisis dengan metode statute approach serta conceptual approach.

\subsection{Teknik Analisis Bahan Hukum}

Analisis bahan hukum dimulai melalui studi pustaka, yaitu diawali dengan invetarisasi dengan mengumpulkan semua bahan hukum yang terkait dengan pokok permasalahan yang ada. Selanjutnya, dilakukan klasifikasi dengan menyeleksi bahan hukum yang relevan yang kemudian disusun dengan sistematis guna menentukan bahan hukum mana yang harus dibaca terlebih dahulu agar dapat lebih mudah untuk dibaca, dipelajari dan dipahami lebih mendalam.

$$
\text { Selanjutnya, melakukan }
$$

pembahasan dengan menggunakan yuridis normatif yakni penalaran yang sifatnya deduktif, yang diawali dari pengetahuan hukum yang bersifat umum, yang diperoleh dari peraturan perundang-undangan dan literatur, yang kemudian diterapkan pada permasalahan yang ada pada penelitian ini sehingga menghasilkan jawaban atas permasalahan yang dibahas tersebut. Untuk memperoleh jawaban tersebut digunakan pembahasan penafsiran sistematis dan penafsiran otentik. Penafsiran sistematis dilakukan dengan menghubungkan pasal-pasal yang satu dengan pasal-pasal lainnya atau peraturan perundang-undangan yang satu dengan yang lainnya.

\section{Pembahasan}

\subsection{Penegakkan Hukum Tindak} Pidana Prank sesuai dengan
Kitab Undang-Undang

Hukum Pidana dan UndangUndang Nomor 11 Tahun 2008 tentang Informasi dan Transaksi Elektronik

Dalam penelitian ini penulis berfokus pada delik pencemaran nama baik. Delik pencemaran nama baik adalah suatu delik aduan dimana seseorang dapat di katakan tercemar nama baiknya apabila ada pihak yang merasa di serang harkat dan martabatnya.

Delik pencemaran nama baik secara yuridis diatur dalam beberapa peraturan perundang-undangan. Penulis akan membahasnya berdasarkan urutan yang aturan Salah satu perbuatan pidana yang sering mengundang perdebatan di tengah masyarakat adalah pencemaran nama baik.

Dalam peraturan perundangundangan di Indonesia, pencemaran nama baik diatur dan dirumuskan dalam Pasal 310 KUHP. yang terdiri dari 3 (tiga) ayat. $^{9}$ Dalam ayat (1) dinyatakan bahwa:

"Barangsiapa sengaja menyerang kehormatan atau nama baik seseorang, dengan menuduh sesuatu hal, yang maksudnya terang supaya hal itu diketahui umum, diancam karena pencemaran, dengan pidana penjara paling lama sembilan bulan atau denda paling banyak tiga ratus rupiah."

Perbuatan yang dituduhkan itu tidak perlu perbuatan yang menyangkut tindak pidana (menipu, menggelapkan, berzina dan sebagainya), melainkan cukup dengan

\footnotetext{
9 Moeljatno, Kitab Undang-Undang Hukum Pidana, Bumi Aksara, Jakarta, 2007 hlm. 114.
} 
perbuatan biasa seperti melacur di rumah pelacuran. Meskipun perbuatan melacur tidak merupakan tindak pidana, tetapi cukup memalukan pada orang yang bersangkutan apabila hal tersebut diumumkan. Tuduhan itu harus dilakukan dengan lisan, karena apabila dilakukan dengan tulisan atau gambar, maka perbuatan tersebut digolongkan pencemaran tertulis dan dikenakan Pasal 310 ayat (2) KUHP ${ }^{10}$, bahwa:

"Jika hal itu dilakukan dengan tulisan atau gambaran yang disiarkan, dipertunjukkan atau ditempelkan di muka umum, maka diancam karena pencemaran tertulis dengan pidana penjara paling lama satu tahun empat bulan atau pidana denda paling banyak empat ribu lima ratus rupiah."

Perumusan Pasal 310 ayat 2

KUHP, yaitu:

"Jika hal itu dilakukan dengan tulisan atau gambaran yang disiarkan, dipertunjukkan atau ditempelkan di muka umum, maka yang bersalah, karena pencemaran tertulis, diancam pidana penjara paling lama satu tahun empat bulan atau denda paling banyak empat ribu lima ratus rupiah".

Berdasarkan rumusan pasal di atas, maka pencemaran dan pencemaran tertulis bedanya adalah bahwa pencemaran tertulis dilakukan dengan tulisan atau gambaran yang disiarkan, dipertunjukkan atau ditempelkan. Sedangkan unsurunur lainnya tidak berbeda.

Kata 'disiarkan' merupakan terjemahan dari bahasa Belanda atas

${ }^{10}$ R. Sugandhi, KUHP dan Penjelasannya, Penerbit Usaha Nasional, Surabaya, 1980. h. 331 kata verspreid yang juga dapat diterjemahkan dengan 'disebarkan'. ${ }^{11}$ 'Disebarkan' atau 'disiarkan' mengandung arti bahwa tulisan atau gambar tersebut lebih dari satu helai atau satu eksemplar. ${ }^{12}$

Kata 'dipertunjukkan' maksudnya bahwa tulisan atau gambar tidak perlu berjumlah banyak tetapi dapat dibaca atau dilihat orang lain. Kata-kata 'disiarkan, dipertunjukkan atau ditempelkan di muka umum' semua bermakna agar dapat dibaca atau dilihat oleh orang lain. ${ }^{13}$

Menghina adalah menyerang kehormatan dan nama baik seseorang. Yang di serang itu biasa merasa malu. Kehormatan yang di serang di sini hanya mengenai kehormatan yang dapat di cemarkan Karena tersinggung.

Dalam pasal 311 ayat (1):

"Barangsiapa melakukan kejahatan menista atau menista dengan tulisan, dalam hal ia di izinkan untuk membuktikan tuduhannya itu, jika ia tidak dapat membuktikan dan jika tuduhan itu dilakukannya sedang di ketahuinya tidak benar, di hukum karena salah memfitnah dengan hukuman penjara selamalamnya empat tahu".

Semua Penghinaan ini hanya dapat di tuntut apabila ada pengaduan dari orang yang menderita. Obyek dari

11 R. Sugandhi, KUHP dan Penjelasannya, Penerbit Usaha Nasional, Surabaya, 1980. h. 331

12 R. Sugandhi, KUHP dan Penjelasannya, Penerbit Usaha Nasional, Surabaya, 1980. h. 331

13 R. Sugandhi, KUHP dan Penjelasannya, Penerbit Usaha Nasional, Surabaya, 1980. h. 331 
pada penghinaan tersebut di atas harus manusia perseorangan, maksudnya bukan istansi pemerintah, pengurus suatu perkumpulan, segolongan penduduk dll.

Kejahatan pencemaran nama baik ini juga tidak perlu dilakukan di muka umum, cukup apabila dapat dibuktikan bahwa terdakwa mempunyai maksud untuk menyiarkan tuduhan tersebut. Pencemaran nama baik (menista) sebenarnya merupakan bagian dari bentuk penghinaan yang diatur dalam Bab XVI KUHP.

Pengertian "penghinaan" dapat ditelusuri dari kata "menghina" yang berarti "menyerang kehormatan dan nama baik seseorang". Korban penghinaan tersebut biasanya merasa malu, sedangkan kehormatan di sini hanya menyangkut nama baik dan bukan kehormatan dalam pengertian seksualitas. Perbuatan yang menyinggung ranah seksualitas termasuk kejahatan kesusilaan dalam Pasal 281-303 KUHP. Penghinaan dalam KUHP terdiri dari pencemaran atau pencemaran tertulis (Pasal 310), fitnah (Pasal 311), penghinaan ringan (Pasal 315), mengadu dengan cara memfitnah (Pasal 317) dan tuduhan dengan cara memfitnah (Pasal 318). ${ }^{14}$

Pencemaran nama baik seseorang atau fitnah adalah ketentuan hukum yang paling sering digunakan untuk melawan media massa. Fitnah yang disebarkan secara tertulis dikenal sebagai libel, sedangkan yang diucapkan atau secara lisan disebut slander.

Sementara itu, Jan Remmelink mengatakan bahwa, "Delik formil adalah tindak pidana yang di dalam

14 R. Soesilo, 1995, Kitab Undang-Undang Hukum Pidana (KUHP) serta Komentarkomentarnya Lengkap Pa- sal Demi Pasal, Politeia, Bogor, hlm. 225. perundang-undangan cukup disebut dengan merujuk pada perbuatan tertentu atau kelalaian ${ }^{15}$. Sedangkan menurut Chazawi, tindak pidana formil adalah tindak pidana yang dirumuskan sedemikian rupa, sehingga memberikan arti bahwa inti larangan yang dirumuskan itu adalah melakukan suatu perbuatan tertentu. Perumusan tindak pidana formil tidak memperhatikan dan atau tidak memerlukan timbulnya suatu akibat tertentu dari perbuatan sebagai syarat penyelesaian tindak pidana, melainkan semata-mata pada perbuatannya. ${ }^{16}$ Delik formil salah satunya terdapat dalam Pasal 310 KUHP.

Secara formil, dalam hal ini tidak dikemukakan apa isi dari penghinaan, melainkan bagaimana pernyataan yang bersangkutan itu dikeluarkan. Bentuk dan caranya yang merupakan faktor menentukan. Pada umumnya cara menyatakan adalah dengan cara-cara kasar dan tidak objektif. Kemungkinan untuk membuktikan kebenaran dari tuduhan tidak ada dan dapat dikatakan bahwa kemungkinan tersebut.

Secara positif-yuridis tindakan pencemaran nama baik melalui media sosial telah di larang dalam UU ITE. Terbukti pada pasal 27 ayat (3) yang merumuskan bahwa:

"Setiap orang dengan sengaja dan tanpa hak mendistribusikan dan/atau membuat dapat di aksesnya informasi elektronik dan/atau dokumen elektronik yang memiliki muatan

\footnotetext{
15 Jan Remmelink, Pengantar Hukum Pidana Material 1 (Inleiding Tot De Studie Van Het Nederlandse Strafrecht), diterjemahkan oleh Tristam P. Moeljono, Maharsa, Yogyakarta, 2014

${ }^{16}$ Adam Chazawi, Op.cit. h.117/
} 
penghinaan

pencemaran nama baik."

Konten yang didistribusikan dan/atau ditransmisikan yang terbukti dapat di aksesnya informasi elektronik dan/atau dokumen elektronik yang memiliki muatan penghinaan dan/atau pencemaran nama baik di pandang sebagai delik cybercrime.

Pemidanaan terhadap pasalpasal di atas di atur dalam pasal 45 ayat (1) yang merumuskan:

"Setiap Orang yang memenuhi unsur sebagaimana di maksud dealam pasal 27 ayat (1), ayat (2), ayat (3), atau ayat (4) dipidana penjara paling lama 6 (enam) tahun dan/atau denda paling banyak Rp.1.000.000.000,00 （satu miliarrupiah)."

Pencemaran nama baik melalui media sosial, sudah masuk dalam delik perbuatan pidana. Baik dengan pasal penghinaan individu maupun pencemaran nama baik yang di atur dalam KUHP maupun UU ITE. Jika pencemaran nama baik ini di teruskan secara terus menerus, orang akan menggunakan media sosial sebagai sarana untuk mencaci-maki, baik terhadap individu maupun kelompok. Pelakunya harus di pidana. Ini bukan hanya melanggar hukum, tapi juga etika dan moral.

Pencemaran nama baik akan menimbulkan permusuhan terhadap seseorang sehingga pencemaran nama baik telah memenuhi kualifikasi rumusan pasal 27 ayat (3) UU ITE. Sanksi yang di terapkan dalam pencemaran nama baik melalui media sosial sesuai dengan pasal 45 ayat (1) UU ITE yaitu dipidana penjara paling lama 6 (enam) tahun dan/atau denda paling banyak Rp.1.000.000,00 (satu miliar rupiah).

\subsection{Langkah Hukum untuk Menjerat Tindak Pidana Prank Berdasarkan KUHP dan UU ITE (Penghinaan Melalui Media Online)}

Jika seseorang menjadi korban tindak perbuatan prank yaitu dijadikan sebagai bahan atau konten dalam video yang diunggah di media online dengan tanpa izin terlebih dahulu dan seseorang (korban) tersebut merasa dilanggar, diserang kehormatannya, dicemarkan nama baiknnya maka pertama kali yang perlu dilakukan adalah dengan menyampaikan keluhan privasi.

Alternatif lain, korban dapat mengadukan orang yang telah menjadikannya sebagai bahan dalam konten video (YouTuber) tersebut melalui laman aduan konten Kementerian Komunikasi dan Informatika Republik Indonesia. Korban harus mendaftarkan diri sebagai pelapor terlebih dahulu dengan mengisi beberapa kolom isian. Aduan yang dikirim harus ada URL/link, screenshot tampilan serta alasannya. Semua laporan yang masuk dan memenuhi syarat (terdapat link/url, screenshot dan alasannya) akan diproses/ditindaklanjuti.

Korban harus mengadukan kepada kepolisian karena tindak pidana penghinaan merupakan delik aduan. Kitab Undang-Undang Hukum Pidana (KUHP) terdapat asas hukum pidana yakni hukum pidana sebagai "hukum publik" dimana ditentukan bahwa "untuk menuntut sesuatu delik, baik yang berupa kejahatan maupun pelanggaran, hak untuk melakukan penuntutan itu diletakkan pada penuntut umum dan pada umumnya 
permintaan dari pihak orang yang menderita atau melakukan penuntutan tidak mempunyai pengaruh terhadap penuntutan ini. ${ }^{17}$

Oleh sebab itu penuntutan peristiwa pidana tersebut tidak dapat diserahkan kepada individu yang dirugikan olehperistiwa pidana itu, tetapi penuntutan tersebut harus dijalankan oleh pemerintah. Hukum pidana dikatakan sebagai hukum publik, karena hukum pidana itu mengatur perhubungan antara individu dengan masyarakat sebagai masyarakat, hukum pidana dijalankan untukkepentingan masyarakat dan juga hanya dijalankan dalam hal kepentinganmasyarakat itu benarbenar memerlukannya. Sifat hukum pidana itu ternyatakhusus dalam hal sering suatu tindakan tertentu tetap menjadi peristiwa pidana,biarpun tindakan itu dilakukan dengan persetujuan yang dikenai akibat tindakantersebut, dan ternyata dalam hal umumnya dituntut tidaknya sesuatu peristiwapidana tidak tergantung pada kehendak dari yang dirugikan oleh peristiwa pidanaitu. Penuntutan suatu peristiwa pidana terletak dalam tangan suatualat negara,yaitu dalam tangan kejaksaan.

Hukum pidana merupakan bagian dari hukum publik. Hal ini berarti bahwa kepentingan umum lebih diutamakan. Karenanya penuntutan suatu delik pada dasarnya dibebankan kepada penguasa karenajabatannya, tidak tergantung pada orang-orang yang menderita sebagai akibat darisuatu delik, bahkan juga andaikan ada keberatan dari penderita, tidak merupakan

17 Barda Nawawi Arief, Masalah Penegakan Hukum dan Kebijakan Penanggulangan Kejahatan, PT. Citra Aditya Bakti, Bandung, 2000, h.127 penghalang bagi usaha penuntutan. Namun demikian dalam hal ini terdapat pengecualian dalam adanya suatu tindakpidana (kejahatan) dimana terhadap beberapa tindak pidana tersebut hanya dapatdituntut apabila ada pengaduan dari orang yang dirugikan. Karenanya apabila kapada suatu Pengadilan/Mahkamah diajukan suatu delik aduan tanpa dilengkapidengan pengaduan(tertulis atau lisan yang dicatat oleh petugas penerima aduan), harus dinyatakan sebagai tidak dapat diterima (niet ontvangkelijk verklaard).

Tindak pidanas eperti itu disebut "klacht delicten" yakni sebagai lawan dari apa yang disebut "gewone delicten" yakni tindak pidana-tindak pidana yang dapat dituntut tanpa diperlukan adanya suatu pengaduan. Delik-delik yang hanya dapatdituntut apabila ada suatu pengaduan dari orang yang merasa dirugikan itu didalam bahasa Belanda disebut "delicten opklachte vervolgbaar" atau dalambahasa Jerman disebut juga "antragsdelikte", yakni sebagai lawan apa yang disebut "delicten van ambtswege vervolgbaar" atau delikdelik yang dituntutsesuai dengan jabatan.

Menurut Memorie Van Theolichting, disyaratkannya suatu pengaduan padabeberapa delik tertentu itu adalah berdasarkan pertimbangan bahwa ikut campurnya penguasa di dalam suatu kasus tertentu itu mungkin akan mendatangkan kerugian yang lebih besar bagi kepentingankepentingan tertentudari orang yang telah dirugikan daripada kenyataan, yakni jika penguasa telahtidak ikut campur di dalam kasus tersebut, sehingga kepentingan apakahseseorang yang telah merugikan itu perlu dituntut atau tidak 
oleh penguasa,haltersebut diserahkan kepada pertimbangan orang yang telah merasa dirugikan.

\section{Delik-delik}

pengaduan penuntutan tergantung daripada orang yang dirugikan.Orang ini menentukan penuntutan, karena tanpa mengajukan penuntutan, ia dapat mencegah penuntutan. Sebaliknya apabila ia mengajukan pengajuan, badan penuntut umum tidak berwajib untuk memberi akibat pada pengaduan yang diajukan. Hal ini disebabkan karena adanya asas opportuniteit, asas tentang kefaedahan penerapan undang-undang, yang merupakan dasar daripada tuntutanpidana pada hukum positif, tetap dipertahankan, sehingga dalam delik-delikpengaduan penguasa yang menuntut, berhak untuk tidak meneruskan perkarademi kepentingan umum. Pernyataan yang benar ialah apakah badan penuntut umum, selama belum diajukan pengaduan, masih berhak untuk mengadakan tindakantindakan pengusutan.

Mengenai pengertian dari pengaduan itu sendiri dalam Kamus Besar Bahasa Indonesia dimuat pengertian antara lain sebagai berikut ${ }^{18}$ : "Mengadukan, mengajukan perkara dan sebagainya (kepada hakim, orangyang berkuasa);....... Pengaduan 1. penyambungan; 2 . aduan (hal atauperkara yang diadukan); 3. Proses, perbuatan, cara mengadu 4. Ungkapan rasa tidak senang atau tidak puas akan hal-hal yang tidakbegitu penting,tetapi perlu diperhatikan".

Melihat pengertian dalam Kamus Besar Bahasa Indonesia tersebut, nampakpersepsi tentang "pengaduan" masih belum jelas, masih

18 Kamus Besar Bahasa Indonesia, Balai Pustaka, Jakarta, 1990, h. 8. kabur bahkan pengertian"mengajukan perkara dan sebagainya" bukan membuat pengertian "pengaduan"semakin jelas.

"Suatu pengaduan adalah suatu pernyataan tegas dari orang yang berhakuntuk mengadu bahwa ia menghendaki penuntutan orang yang telahmelakukan pelanggaran pidana itu".

Jika tidak berbentuk tertulis, akansulit dipergunakan karena tanggal pengajuan maupun waktu untuk mencabut akan sulit ditentukan. Dengan demikian maka suatu pengaduan adalah pernyataantertulis dari orang yang berhak untuk mengadu bahwa ia menghendaki penuntutanpelaku suatu kejahatan atau tindak pidana. Orang yang "mengadu", jika yang menderita atau korban kejahatan suatu tindakpidana, sudah dewasa maka tidak menimbulkan permasalahan karena korbanitulah yang berhak mengadu.

Masalah timbul, jika korban suatu tindak pidanaaduan, belum dewasa. Hal ini merupakan bagian dari kebijakan formulasi dalamhal menyangkut tindak pidana yang dikualifikasikan sebagai delik aduan yangakan dibahas pada bab selanjutnya.Pengertian "pengaduan" sebagai unsur dari tindakpidanayang dikualifikasikansebagai delik aduan, maka perlu dibedakan "pengaduan" dengan "laporan".

Perbedaan antara pengaduan dan laporan adalahsebagai berikut :

1. Pelaporan dapat diajukan terhadap semua perbuatan pidana,sedang pengaduanhanya mengenai kejahatan-kejahatan untuk mana adanya pengaduan itumenjadi syarat/unsur. 
2. Setiap orang dapat melaporkan suatu kejadian, sedangkan pengaduan hanyadapat diajukan oleh orang-orang yang berhak mengajukannya.

3. Laporan tidak menjadi syarat untuk mengadakan tuntutan pidana, pengaduansebaliknya di dalam kejahatan-kejahatan tertentu merupakan syarat untukmengadakan penuntutan.

Penghinaan merupakan delik aduan absolut. Delik aduan absolut adalah delik aduan yang dalam keadaan apapun tetapmerupakan delik aduan. Atau menurut kata-kata Vos : "Absolute zijn die,welkeals regel allen op klchte vervolgbaar zijn....". Tindakan pengaduan di sini diperlukan untuk menuntut peristiwanya, sehingga semua yang bersangkutan dengan itu harus dituntut

Selain itu, korban bisa datang langsung dan membuat laporan kejadian ke Kepolisian terdekat, atau jika korban berada di wilayah Jakarta, bisa membuat laporan kejadian pada Subdirektorat Penyidikan Direktorat Keamanan Informasi Kementerian Komunikasi dan Informatika.

Korban penghinaan juga dapat menuntut secara pidana terhadap perbuatan penghinaan/pencemaran nama baik melalui video yang diunduh di youtube, dengan cara sebagai berikut:

1. Orang yang merasa haknya dilanggar atau melalui kuasa hukum, datang langsung membuat laporan kejadian kepada penyidik POLRI pada unit/bagian Cybercrime atau kepada penyidik PPNS (Pejabat Pegawai Negeri Sipil) pada Sub Direktorat Penyidikan dan Penindakan, Kementerian Komunikasi dan Informatika. Selanjutnya, penyidik akan melakukan penyelidikan yang dapat dilanjutkan dengan proses penyidikan atas kasus bersangkutan Hukum Acara Pidana dan ketentuan dalam UU ITE.

2. Setelah proses penyidikan selesai, maka berkas perkara oleh penyidik akan dilimpahkan kepada penuntut umum untuk dilakukan penuntutan di muka pengadilan. Apabila yang melakukan penyidikan adalah PPNS, maka hasil penyidikannya disampaikan kepada penuntut umum melalui penyidik POLRI.

Mengingat delik penghinaan dalam UU ITE dan perubahannya merupakan delik aduan, maka kehadiran korban sebagai pelapor atau "orang yang merasa menjadi korban penghinaan" sangat dibutuhkan, khususnya untuk membuktikan konten dan konteks dari penghinaan sebagaimana dimaksud. Kelengkapan yang harus disiapkan adalah identitas pribadi dan sekiranya ada, dapat disampaikan bukti penghinaan sebagaimana dimaksud. Biasanya, selain diminta membuat Laporan Kejadian (LK), korban juga akan dimintai keterangan tertulis yang akan dituangkan dalam Berita Acara Pelapor.

Jika media yang digunakan untuk menyebarkan konten video atau gambar adalah Facebook, dan konten yang diunggah di Facebook yang dianggap menghina seseorang telah dihapus oleh terlapor, maka korban dapat menyampaikannya kepada penyidik dalam Laporan Kejadian. Dalam banyak kasus, pengelola Facebook masih menyimpan log data status pengguna Facebook untuk periode tertentu berdasarkan pertimbangan kebijakan internal Facebook. Oleh karena itu, sebaiknya sesegera mungkin korban melaporkan 
kejadian tersebut kepada pihak berwenang sebagaimana disebutkan di atas.

Alternatif lainnya, korban dapat mengadukannya melalui laman Aduan Konten dari Kementerian Komunikasi dan Informatika Republik Indonesia. Korban harus mendaftarkan diri sebagai pelapor terlebih dahulu dengan mengisi beberapa kolom isian. Aduan yang dikirim harus ada URL/link, screenshot tampilan serta alasannya. Semua laporan yang masuk dan memenuhi syarat (terdapat link/url, screenshot dan alasannya) akan diproses/ditindaklanjuti.

Jadi penting juga untuk mengambil screenshot atas status Facebook yang diunggah oleh orang yang menghina, sebelum orang tersebut menghapusnya, untuk kemudian dijadikan bukti atau syarat untuk mengirim aduan.

Langkah lain yang dapat korban lakukan adalah dengan mengunjungi Pusat Bantuan yang disediakan oleh Facebook kemudian mengisi Formulir Pelaporan Penghinaan. Formulir ini ditujukan untuk melaporkan konten yang dikirimkan di Facebook yang diyakini oleh korban sebagai penghinaan berdasarkan undang-undang yang melanggar hak legal personal korban. Jenis laporan lain tidak akan ditangani melalui formulir ini. Sebelum menuntut pembuat konten itu di Facebook bersifat penghinaan, korban sebaiknya berkonsultasi dengan pengacara yang berkualifikasi.

Sementara itu, secara formil, tidak dikemukakan apa isi dari penghinaan, melainkan bagaimana pernyataan yang bersangkutan itu dikeluarkan. Bentuk dan caranya yang merupakan faktor menentukan. Pada umumnya cara menyatakan adalah dengan cara-cara kasar dan tidak objektif. Kemungkinan untuk membuktikan kebenaran dari tuduhan tidak ada dan dapat dikatakan bahwa kemungkinan tersebut.

Dalam RKUHP 2015 mengenai pencemaran nama baik mendapat beberapa perubahan dibanding KUHP sebelumnya. RKUHP 2015 tentang pencemaran nama baik sudah cukup jelas karena telah mengatur dalam media apa perbuatan tersebut dilakukan. Dapat diketahui bahwa pencemaran nama baik dalam RKUHP 2015 diatur dalam Buku II Bab XIX Pasal 537 ayat (1) dimana dalam pasal tersebut mengatur bagi setiap orang yang dengan lisan menyerang kehormatan atau nama baik oranglain dengan cara menuduhkan suatu hal dengan maksud agar dapat diketahui umum. Sedangkan dalam UU ITE belum mendapatkan perubahan pada Pasal 27 ayat (3). Oleh karena itu, UU ITE dimasa yang akan datang perlu diperjelas lagi perbuatan tersebut dilakukan dalam media apa beserta batasannya, karena untuk meminta pertanggungjawaban pidana maka perbuatan yang dilakukan oleh pelaku tersebut harus sangat jelas dilakukan dalam media apa.

Untuk menanggulangi tindak pidana pencemaran nama baik di media sosial yaitu memberikan tuntutan hukuman maksimal dengan menggunakan Pasal yang sesuai dengan tindak pidana pencemaran nama baik yang dilakukan berdasarkan KUHP dan Undang-Undang ITE, agar memberikan efek jera kepada pelaku tersebut.

Di samping itu, pembuktian merupakan salah satu factor yang sangat penting, mengingat informasi elektronik bukan saja belum terakomodasi dalam system hukum 
acara Indonesia secara kompherensip, melainkan juga ternyata sangat rentan untuk di ubah, di sadap, di palsukan, dan di kirim ke penjuru dunia dalam waktu hitungan detik. Dengan demikian, dampak yang di akibatkannya pun bisa demikian kompleks dan rumit. Pencemaran nama baik melalui media sosial, sudah masuk dalam delik perbuatan pidana. Baik dengan pasal penghinaan individu maupun pencemaran nama baik yang di atur dalam KUHP maupun UU ITE. Jika pencemaran nama baik ini di teruskan secara terus menerus, orang akan menggunakan media sosial sebagai sarana untuk mencaci-maki, baik terhadap individu maupun kelompok. Pelakunya harus di pidana. Ini bukan hanya melanggar hukum, tapi juga etika dan moral.

\section{Penutup}

\subsection{Kesimpulan}

1. Penegakkan hukum tindak pidana prank (penghinaan yang diunggah di media online) adalah :

a. Sesuai dengan Kitab UndangUndang Hukum Pidana Pasal 310 KUHP, dengan ketentuan pidana penjara paling lama 9 bulan. Jika hal itu dilakukan dengan tulisan atau gambar yang disiarkan, dipertunjukan atau ditempelkan dimuka umum, maka diancam karena pencemaran tertulis dengan pidana penjara paling lama 1 tahun 4 bulan. Tidak merupakan pencemaran atau pencemaran tertulis, jika perbuatan jelas dilakukan demi kepentingan umum atau terpaksa untuk membela diri.

b. Sesuai dengan Pasal 45 ayat (1) Undang-Undang Nomor 11 Tahun 2008 tentang Informasi dan Transaksi Elektronik, dengan pidana penjara paling lama 6 (enam) bulan dan/atau denda paling banyak Rp. 1.000.000.000,00 (satu milyar rupiah).

2. Langkah hukum untuk menjerat tindak pidana yang sesuai dengan dengan Kitab Undang-Undang Hukum Pidana dan UndangUndang Nomor 11 Tahun 2008 tentang Informasi dan Transaksi Elektronik adalah sebagai berikut, mengajukan Keluhan Privasi sebagai korban penghinaan atau pencemaran nama baik atau mengadukan pelaku yang melakukan tindak pidana prank (penghinaaan mealului mediaonline) melalui laman aduan konten dari Kementerian Komunikasi dan Informatika Republik Indonesia. Bisa juga dengan cara datang langsung dan membuat laporan kejadian ke Kepolisian terdekat, atau jika korban berada di wilayah Jakarta, bisa membuat laporan kejadian pada Subdirektorat Penyidikan Direktorat Keamanan Informasi Kementerian Komunikasi dan Informatika. Orang yang merasa haknya dilanggar atau melalui kuasa hukum, datang langsung membuat laporan kejadian kepada penyidik POLRI pada unit/bagian Cybercrime atau kepada penyidik PPNS (Pejabat Pegawai Negeri Sipil) pada Sub Direktorat Penyidikan dan Penindakan, Kementerian Komunikasi dan Informatika. Selanjutnya, penyidik akan melakukan penyelidikan yang dapat dilanjutkan dengan proses penyidikan atas kasus bersangkutan Hukum Acara Pidana dan ketentuan dalam UU ITE. Setelah proses 
penyidikan selesai, maka berkas perkara oleh penyidik akan dilimpahkan kepada penuntut umum untuk dilakukan penuntutan di muka pengadilan. Apabila yang melakukan penyidikan adalah PPNS, maka hasil penyidikannya disampaikan kepada penuntut umum melalui penyidik POLRI.

\subsection{Saran}

1. Para aparat perlu pembekalan dan pelatihan-pelatihan khusus mengenai ITE sehingga dalam menghadapi penerapan kasus ITE tetap mampu melindungi korban, tapi jangan sampai para aparat penegak hukum salah menafsirkan ketentuan pasal sehingga digunakan secara membabi buta.

2. Melakukan pembaharuan peraturan hukum yang digunakan dalam penyelesaian terhadap cybercrime seperti kasus pencemaran nama baik melalui youtube dengan melakukan perbandingan dengan hukum negara lain seperti di Amerika yang tidak lagi mencantumkan hukuman penjara terhadap pelaku pencemaran nama baik, hanya berupa hukuman denda.

3. Masyarakat selaku pengguna jejaring Sosial hendaknya harus memahami dan lebih arif dan bijaksana didalam memberikan pendapat ataupun berekspresi di media sosial dan haruslah tetap sesuai dengan etika dan koridor hukum yang berlaku sehingga dengan tidak mudah terjerat dengan ketentuan Pasal 27 ayat (3) UU ITE tersebut.

\section{DAFTAR PUSTAKA}

Adji, Oemar Seno, Perkembangan Delik Pers di Indonesia, Erlangga, Jakarta, 1990.
Arief, Barda Nawawi, Masalah Penegakan Hukum dan Kebijakan Penanggulangan Kejahatan, PT. Citra Aditya Bakti, Bandung, 2000.

Chazawi, Adami, Pelajaran Hukum Pidana (Stelsel Tindak Pidana, Teori-Teori Pemidanaan \& Batas Berlakunya Hukum Pidana), Raja Grafindo Persada, Bandung, 2002.

Echols, John M. dan Hassan Shadily, Kamus Inggris-Indonesia, PT. Gramedis Jakarta, 2008

Kamus Besar Bahasa Indonesia, Balai Pustaka, Jakarta, 1990.

Lamintang, P.A.F, Dasar-dasar Hukum Pidana Indonesia, Citra Aditya Bakti, Jakarta, 1997.

Moeljatno, Kitab Undang-Undang Hukum Pidana, Bumi Aksara, Jakarta, 2007.

Mudzakir, ADR; Penyelesaian Perkara Pidana dalam Sistem Peradilan Pidana Indonesia, Makalah Workshop, Jakarta.

Remmelink, Jan, Pengantar Hukum Pidana Material 1 (Inleiding Tot De Studie Van Het Nederlandse Strafrecht), diterjemahkan oleh Tristam P. Moeljono, Maharsa, Yogyakarta, 2014.

Soesilo, R, Kitab Undang-Undang Hukum Pidana (KUHP) Serta Komentar-Komentarnya Lengkap Pasal Demi Pasal, Politeia, Bogor, 1995.

Sugandhi, $\quad R, \quad$ KUHP dan Penjelasannya, Penerbit Usaha Nasional, Surabaya, 1980. 
